IRA-International Journal of Management \&

Social Sciences

ISSN 2455-2267; Vol.13, Issue 02 (November, 2018)

Pg. no. 48-64.

Institute of Research Advances

http://research-advances.org/index.php/RAJMSS

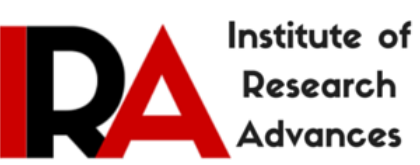

\title{
An Analytical Study of the Effect of Inflation on Stock Market Returns
}

\section{Dr. S. Sathyanarayana ${ }^{1 \#}$, Prof. Sudhindra Gargesa ${ }^{1}$}

${ }^{1}$ Professor, MP Birla Institute of Management, Bangalore, India.

\#corresponding author.

Type of Review: Peer Reviewed.

DOl: http://dx.doi.org/10.21013/jmss.v13.n2.p3

Sathyanarayana, S., Gargesa, S. (2018). An Analytical Study of the Effect of Inflation on Stock Market Returns. IRA-International Journal of Management \& Social Sciences (ISSN 2455-2267), 13(2), 48-64. doi:http://dx.doi.org/10.21013/jmss.v13.n2.p3

\section{(C) Institute of Research Advances.}

\section{(cc) EY-NC}

This work is licensed under a Creative Commons Attribution-Non Commercial 4.0 International License subject to proper citation to the publication source of the work.

Disclaimer: The scholarly papers as reviewed and published by the Institute of Research Advances (IRA) are the views and opinions of their respective authors and are not the views or opinions of the IRA. The IRA disclaims of any harm or loss caused due to the published content to any party.

Institute of Research Advances is an institutional publisher member of Publishers International Linking Association Inc. (PILA-CrossRef), USA. The institute is an institutional signatory to the Budapest Open Access Initiative, Hungary advocating the open access of scientific and scholarly knowledge. The Institute is a registered content provider under Open Access Initiative Protocol for Metadata Harvesting (OAI-PMH).

The journal is indexed \& included in WorldCat Discovery Service (USA), CrossRef Metadata Search (USA), WorldCat (USA), OCLC (USA), Open J-Gate (India), EZB (Germany) Scilit (Switzerland), Airiti (China), Bielefeld Academic Search Engine (BASE) of Bielefeld University, Germany, PKP Index of Simon Fraser University, Canada. 


\begin{abstract}
Inflation means a persistent change in the price level of goods and services in an economy. It is generally measured in the consumer price index (CPI) or retail price index (RPI). Inflation reduces the purchasing power of a country's currency, as we need more units of currency over time to buy the same goods and services. The current empirical paper entitled "relationship between inflation and stock market evidence from selected global stock markets" have been undertaken with an intention to investigate the relationship between inflation and stock returns of the chosen economies. In order to realise the stated objectives the researchers have collected the monthly data 2000 to 2017 for selected indices. In the first phase log returns were computed and it has been tested for the existence of unit root in the distribution. In the second phase we ran Pearson correlation coefficient for the collected data to find out the association between the inflation and stock returns. Majority of the chosen indices recorded a negative coefficient with the dependent variable. For India, Austria, Belgium, Canada, Chile, China, France, Ireland we found a negative coefficient. However, Brazil Indonesia, Japanese, Mexico, Spanish and Turkey reported a positive coefficient. Current study clearly throws light on the effect of inflation on the stock market returns therefore; it can help the market participants such as traders, fund managers and investors to make good portfolio decisions based on the information about expected inflation and unexpected inflation. The study confirms that there exists a significant relationship between the stock returns and inflation for Australian, Belgium, Canadian, Chilean, Chinese, French and Irish stock benchmark indices. Firms can take this one has a clue to adjust their reported profits by raising the prices. The policy makers can employ contractionary policy to reduce the supply of money by offering low interest rate on $t$ bills, increasing the interest rates (bank rate policy) and increasing the cash reserve ratios which in turn reduces the lending capacity of the banks.
\end{abstract}

Keywords: Inflation, CPI, WPI, Real returns, Serial Correlation, ADF stats.

\title{
I INTRODUCTION
}

There is no universally accepted definition for inflation. Inflation is the persistent change in general price level for goods and services on a year-on year basis. In any economy inflation crops up when the amount of purchasing power is greater than the amount of goods and services. Generally inflation may be a boost in the volume of currency that causes the increase in prices. From the consumer's perspective, a low inflation is always better than high inflation, because their spending on necessities is not surging faster than their incomes. On the other hand, high inflation introduces uncertainty. Depending on the depth of inflation, the economists have classified inflation into different types, namely. (i) Creeping Inflation (weak) (ii) Galloping Inflation (faster than creeping inflation) (iii) Hyperinflation (a very high rate of inflation) (iv) stagflation (inflation and recession occur together) and (v) deflation is the reverse of inflation (decline in the general price level). The major threat from inflation is that it erodes the purchasing power of currency. It discourages investment, reduces the value of savings, high inflation leads to fall in real wages. Apart from it inflation has a regressive effect on lower- income strata and senior citizens of the society. Real interest rate on bank deposits may be negative. Higher borrowing cost for business and industry borrowers. An economy with high inflation rate, makes it exports less competitive in global markets, reduces the exports, less job or no job creation, increase the business uncertainty and adverse effect on balance of payment. There are different ways to measure inflation.

Generally, on the basis of target population, the inflation indices are generated to record the price level changes for example, end users, manufactures, wholesalers, retailers etc. These indices may be CPI (Consumer Price Index), (PPI) Producer Price Index, (WPI) Wholesale Price index etc. However, in India inflation is measured over two major indices, WPI and CPI. Most of the developing nations use CPI as the measure to understand the levels of inflation. According to PIMCO, if economic growth stimulate very rapidly, demand grows even faster and service providers and manufactures rises prices continually. This is called hyperinflation, this phenomenon occurs when consumers spending exceeds the production of goods and services. This results in the decline in the purchasing power of the currency. On the other hand, when economic activity begins to slow, demand decreases and the supply of goods and services exceeds the demand. At this time, the inflation rate falls. This phenomenon is called disinflation. The extended weak demand can lead to deflation or recession or even trade depression. In the words of Schofman and Schweitzer (2000) increasing inflation is one of the major concern for investors because it decreases the real return on their investments. 
History has demonstrated that high inflation can affect the economy in so many ways: for example high inflation creates uncertainty and high level of volatility in stock market. It may slow down the economic activities in the economy. Therefore, investigating the impact of inflation on stock market performance has implications for market participants and policy makers. The remainder of this paper is organized as follows. Section two discuses a review of previous empirical papers from the proposed title. Section three deals with the research methodology employed for the study. In section Four the empirical results are discussed and in the closing section discussion and conclusion have been drawn and the empirical findings are compared with the available evidence.

\section{LITERATURE REVIEW}

The efficiency of major global stock markets has been investigated through many empirical studies. According to these studies volatility in stock markets are caused by various macro-economic factors such as GNP (Wongbampo and Sharma (2002)), inflation (Geske and Roll (1983); DeFina (1991); Naka (1994), Geetha et al. (2011); Aggarwal (1981), Soenen and Hennigar (1988), money supply (Urich and Wachtel (1981) Chaudhuri and Smiles (2004); Ibrahim (2000) (Ahmed \& Osman (2007) (Tivoli and Bulmash (1996) Roley (1985); Toda and Yamamoto (1995)), Jain (1988) Cheng (1995) interest rates (Pan et al. (2007); Asperm (1989); Nissim and Penman (2003) Bohl et al. (2007)), interest rate (Bhattacharya and Mukherjee (2002); Ahmed (2008)), and exchange rate (Robert (2008)) Fang and Miller (2002) Akinnifesi (1987) Hennigan (1988), Bahmani and Sohrabian (1992) money supply , 91 day T-bill rate, interest rate GDP (Pilinkus (2009)) and industrial production index. currency demonetisation (Sathyanarayana (2017), real GDP Schwert (1990) or industrial production, exchange rates Robert Johnson (2010); Agrawal (1981), Oil prices (Robert (2008)); Bacon and Kojima (2008), Umut (2010) Kaul (1996)); devaluation in currency Granger, Husang and Young's (2008); Currency depreciation (Heinz Herrmann et al. (2006)); Real economic activity (Abdullah and Hayworth 1993, , Fama 1981, Huang and Kracaw (1984); returns and long- term bonds (Fama and French, 1989), budget deficits (Darrat, 1990a;) BREXIT referendum (Sathyanarayana (2017) (Sathyanarayana (2016)) etc. when it comes inflation, majority of the studies focused on two types of inflation. They are expected inflation and unexpected inflation. According to economic theory, the expected inflation is not a risk for stock returns and only the unexpected inflation is a major threat for stock returns. Financial market participants are always ardent about the relationship between inflation and other macroeconomic factors such as economic growth for example Fischer (1993) empirically documented that growth rate and inflation share inverse relationship; Barro (1995) supported the view of Fischer. However, Bruno and Easterly (1996) examined the relationship between inflation and growth conclude that this relationship is temporary and the inverse relationship documented by Fischer (1993) exists only when there are high inflation rate Sarel (1997) supported this view. Even Rangarajan (1998), argued that inflation has negative impact on growth rate of an economy because of its destructive effects on productivity and efficiency. However, empirical studies conducted by Tun Wai, (1959); Paul, Kearney and Chowdhury (1997) did not find any evidence between these two variables. Cordon (1990) in his empirical study documented that low inflation is significantly related with high growth rate. Another group of researchers tried to investigate the relationship between the Inflation and GDP Ghosh and Phillips (1998) and they documented a negative coefficient between the two variables. Boyd, Levine and Smith (1996), investigated the relationship between inflation and financial system. The study revealed that and concluded that inflation shares negatively correlated with financial markets. Yet another study was conducted by English (1999) to assess the relationship between inflation and financial development found a positive relationship, similar studies were conducted by Haslag, J. and Koo (1999) Michelle Barnes (2000) Boyd, Levine, and smith (2001), Rousseau and Wachtel (2001).

The relationship between stock returns and rate of inflation has been examined extensively in the literature. However, the findings of these empirical studies were mixed. Fisher (1930) in his empirical investigation found a positive relationship between the stock returns and inflation and suggested that equities shares should be used as a hedge against inflation. Bodie (1976) provide evidence in favour of this argument. Later most of the studies documented the same evidence for example, Lintner, 1975; Jaffe and Mandelker, 1976; Gultekin, 1983; Choudhry, 2001 Feldstein (1980); Kessel (1956); Samarakoon (1996) Akmal (2007) found a positive relationship between stock prices and higher inflation rate. Similar findings were documented by Fama (1981); Boudhouch and Richarson, (1993). Further, in an empirical study by Fama and Schwert (1977) documented an inverse relationship between expected and unexpected inflation and stock returns. They argued that increase in the development activities, results in the shrinkage of inflation. This results in increase in the equity prices. 
Similar findings were documented by Nelson (1976); Jaffe and Mandelker (1977); Yeh and Chi (2009) David A. Marshall (1992). Firth, (1979) investigated this relationship in United Kingdom stock market and demonstrated a positive relationship between these two variables. However, another stream of researcher found an inverse relationship between the inflation and stock returns. For example Ioannides et al, (2005); Spyrou, (2001) documented a negative relationship between these two variables.

Zhao (1999) in his empirical study conducted in China documented a significant negative relationship between inflation and stock market. Bethlehem (1972) investigated the relationship between inflation and stock market returns in JSE on a sample of 20 listed stocks. He concluded that stocks were very good hedges against inflation. In a study by Bakshi and Chen (1996) documented a negative correlation between inflation and stock prices. In an empirical study by Spyrou (2001) tried to investigate the relationship between these two variables in Greece found a negative and statistically insignificant relationship. Rao and Bhole (1990) investigated the impact of inflation on equity market returns in Indian stock market. For examining this, they estimated nominal and found a negative relationship between inflation and stocks returns and positive return for long run. Munene (2007), in an investigation found an inverse relationship between expected inflation and a direct relationship between actual inflation and stock prices.

The literature review on the proposed topic has demonstrated that stock return and inflation are interlinked. There is no unanimity on whether the relationship that exists between inflation and stock returns are positive or negative or neutral. Empirical evidence regarding this relationship in Indian stock market and other developing stock markets seems scarce in the literature. It is in the light of this that the relationship between the stock market returns and inflation is being undertaken.

\section{RESEARCH DESIGN}

Data for the Purpose of the Study: As the current study was analytical, quantitative and historical in nature, the data collected for the study purpose was chiefly from secondary sources. For the current empirical study the data was collected from various data bases such as capital line, yahoo finance and other web sources. For the purpose of the study the major index from the selected nation has been selected for example India (Sensex), Austria (ATX), Belgium (BEL20), Brazil (Bo Vespa), Canada (GSPTSE), Chile (IPSA), China (SSEC), France (FCHI), Indonesia (JKSE), Ireland (ISEQ), Japan (Nikkei), Mexico (MXX), Spain (IBEX ) and Turkey (XU100.ES) the adjusted closing price for the chosen indices have been collected.

\section{Specification of the Model}

The following linear regression model has been used to test the theoretical relation between stock return and inflation rate

$\mathrm{Y}=\mathrm{a}+\mathrm{b}_{1} \mathrm{X}_{1}+\mathrm{C}$

Where $\mathrm{Y}=$ Dependent variable (Stock returns)

$\mathrm{a}=$ constant intercept term of the model

$\mathrm{b}_{1}=$ coefficients of the estimated model

$\epsilon=$ error component

Objectives of the study

1. To analyse the relationship between stock returns and inflation.

2. To investigate the impact of inflation on stock index.

3. To offer suggestions based on this empirical study to the policymakers and market participants.

Hypothesis of the Study

H0: there is no significant relationship between independent variable (Inflation) and stock returns.

H1: there is a significant relationship between independent variable (Inflation) and stock returns.

\section{Plan of Analysis}

To investigate the impact of inflation on the chosen indices the following methodology has been employed. In the first phase the collected data has been tested for unit root by employing ADF test(Dickey and Fuller 1979). In the second phase, Descriptive statistics have been run to understand the data distribution and to eliminate the outliers from the data. In the third phase a linear regression model has been run to test the proposed relationship between the variables. In the last phase, residual diagnostics such as B-G Serial correlation LM test, BreuschPagan-Godfrey heteroskedasticity test and CUSUM test have been run to assess the strength of the constructed regression model. However, for Sensex and Inflation in India, we ran Johansen cointegration test to investigate the association between the dependent and independent variable. Later VECM and Wald stats have been run to assess the short run association. Finally the results have been compared with the possible evidence. 
IV DATA ANALYSIS

TABLE NO 4.1 TABLE SHOWING DESCRIPTIVE STATISTICS (INFLATION)

\begin{tabular}{|l||l||c|c|c||c||c||c||}
\hline & India & Austria & Belgium & Brazil & Canada & Chile & China \\
\hline \hline Mean & 6.666 & 1.939 & 1.996493 & 6.801823 & 1.917 & 3.368 & 2.255 \\
\hline \hline SE & 0.212 & 0.060 & 0.087604 & 0.185098 & 0.064 & 0.141 & 0.149 \\
\hline \hline SD & 3.027 & 0.858 & 1.254301 & 2.643733 & 0.919 & 2.025 & 2.122 \\
\hline \hline Variance & 9.165 & 0.737 & 1.573271 & 6.989323 & 0.845 & 4.100 & 4.502 \\
\hline \hline Surtosis & -0.026 & -0.389 & 0.938212 & 4.62134 & 0.883 & 1.981 & 0.444 \\
\hline \hline Count & 0.753 & 0.118 & 0.058331 & 1.913294 & 0.038 & 0.686 & 0.687 \\
\hline & 204 & 204 & 205 & 204 & 204 & 205 & 204 \\
\hline \hline Mean & France & Indonesia & Ireland & Japan & Mexico & Spain & Turkey \\
\hline \hline SE & 3.223 & 7.242 & 2.027 & 0.0279 & 4.467 & 2.212 & 15.981 \\
\hline \hline SD & 0.155 & 0.248 & 0.189 & 0.0742 & 0.101 & 0.115 & 1.156 \\
\hline \hline Variance & 3.129 & 3.551 & 2.696 & 1.0600 & 1.447 & 1.646 & 16.547 \\
\hline \hline Kurtosis & 9.792 & 12.613 & 7.269 & 1.1236 & 2.093 & 2.710 & 273.810 \\
\hline Skewness & 5.897 & 0.907 & 0.921 & 2.3695 & 3.025 & -0.759 & 2.998 \\
\hline Count & 2.200 & 1.087 & -0.845 & 1.1947 & 1.566 & -0.626 & 2.049 \\
\hline
\end{tabular}

The role of descriptive statistics is to describe the patterns, trends and summarises the given data set in a meaningful way. It is evident from the above table that Inflation rate in India has a mean score of 6.666, with a variance of 9.165 (which is considered to be very high) for 204 data points. For Austria the mean Inflation rate documented was 1.939 with a variance of 0.737 for 204 data points. For Belgium the recorded inflation mean of inflation was 1.996 with a variance of 1.573 , followed by Brazil 6.802 with a variance of 6.989 which is very high, Canada with a reported mean of 1.917 with a variance of 0.845 (the least variance among the chosen sample). Chile has recorded a mean inflation rate of 3.368 with a variance of 4.100 . For China the reported average inflation was 2.255 with a variance of 4.502 . France's mean inflation rate stood at 3.223 with a variance of 9.792. Indonesia has reported a mean inflation rate of 7.242 for the study period with a variance of 12.613 (significantly very high variance). Ireland has documented 2.027 mean of inflation rate with a variance of 7.269. Japan recorded the least mean inflation rate among the chosen sample with 0.0279 with a variance of 1.1236. Mexico has recorded the mean inflation of 4.467 with a variance of 2.093. However, Spain has documented a mean inflation rate of 2.212 with a variance of 2.710. Turkey has recorded a mean inflation rate of 15.981 with the highest variance of 273.810. Based on the above analysis we can infer that majority of the developing nations have the high mean inflation rate and high degree of volatility in inflation rate.

\section{DATA ANALYSIS}

TABLE NO 4.2 TABLE SHOWING DESCRIPTIVE STATISTICS (STOCK INDICES)

\begin{tabular}{|l||r||r|r||r||r||r|r|}
\hline & \multicolumn{1}{|l|}{ India } & \multicolumn{1}{c|}{ Austria } & \multicolumn{1}{c|}{ Belgium } & \multicolumn{1}{c|}{ Brazil } & Canada & \multicolumn{1}{c|}{ Chile } & \multicolumn{1}{c|}{ China } \\
\hline \hline Mean & 0.009069 & 0.004884 & 0.00157 & 0.007045 & 0.002506 & 0.007872 & 0.002512 \\
\hline \hline SE & 0.004697 & 0.004286 & 0.003433 & 0.005045 & 0.00285 & 0.003242 & 0.00563 \\
\hline \hline SD & 0.067257 & 0.061362 & 0.049033 & 0.072057 & 0.040703 & 0.043731 & 0.080209 \\
\hline Variance & 0.004523 & 0.003765 & 0.002404 & 0.005192 & 0.001657 & 0.001912 & 0.006434 \\
\hline \hline Kurtosis & 1.891357 & 5.342254 & 4.200621 & 0.684019 & 3.191606 & 0.377591 & 1.676233 \\
\hline \hline Skewness & -0.50021 & -1.45066 & -1.40123 & -0.39176 & -1.15616 & 0.153116 & -0.53295 \\
\hline Count & 205 & 205 & 204 & 204 & 204 & 204 & 203 \\
\hline \hline & France & Indonesia & Ireland & Japan & Mexico & Spain & Turkey \\
\hline \hline Mean & -0.00097 & 0.012447 & 0.001188 & 0.000964 & 0.009823 & -0.00033 & 0.007819 \\
\hline SE & 0.003635 & 0.00451 & 0.004103 & 0.003996 & 0.003643 & 0.004086 & 0.007214 \\
\hline \hline SD & 0.05192 & 0.064262 & 0.058595 & 0.057068 & 0.052038 & 0.058357 & 0.103032 \\
\hline
\end{tabular}


IRA-International Journal of Management Eి Social Sciences

\begin{tabular}{||l||r||r|r||r|r|r|r||}
\hline \hline Variance & 0.002696 & 0.00413 & 0.003433 & 0.003257 & 0.002708 & 0.003406 & 0.010616 \\
\hline \hline Kurtosis & 0.872622 & 6.063164 & 2.005335 & 1.702961 & 1.306025 & 0.738521 & 2.627566 \\
\hline \hline Skewness & -0.642 & -1.20394 & -0.98771 & -0.76517 & -0.50636 & -0.46476 & -0.19399 \\
\hline \hline Count & 204 & 203 & 204 & 204 & 204 & 204 & 204 \\
\hline
\end{tabular}

It is evident from the above table that the monthly mean returns for Sensex for the study period was 0.009069 with a variance of 0.004523 . For Austria the mean Index returns were 0.004884 with a variance of 0.003765 for 205 data points. For Belgium the recorded mean returns were 0.00157 with a variance of 0.002404 , followed by Brazil 0.007045 with a variance of 0.005192. Canadian Index has reported a mean returns of 0.002506 with a variance of 0.845 . Chile has recorded a mean returns of 0.007872 with a variance of 0.001912 . China the reported a mean return of 0.002512 with a variance of 0.006434 . However France has reported a mean returns of -0.00097 with a variance of 0.002696 . Indonesia has reported a mean of 0.012447 for the study period with a variance of 0.00413 . Whereas, Ireland has documented 0.001188 mean with a variance of 0.003433 . Japan recorded the mean returns of 0.000964 with a variance of 0.003257 . Mexico has recorded the mean returns of 0.009823 with a variance of 0.002708 . However, Spain has documented a mean returns of 0.00033 with a variance of 0.003406 . Turkey has recorded a mean returns of 0.007819 with the highest variance of 0.010616 . It is evident from the above analysis that Indonesian Index market has recorded that highest mean returns, followed by Mexico and India. However France Stock Index recorded the least the negative mean returns for the study period, Spain occupied the penultimate position with -0.00033 , whereas Japan stood twelfth position with 0.000964. However, in case of variance, Turkey's stock market was reported to have a high degree of volatility, followed by China with 0.006434 and Brazil with 0.005192. However, Canadian stock markets reported the least volatility with 0.001657 , Chile with 0.001912 and Belgium with 0.002404 the least risky stock markets for the study period.

ADF test has been applied to determine the existence of the unit root in the time series data. For this purpose the test has been conducted at unit root in Level, 1 st difference and $2^{\text {nd }}$ difference. For this purpose intercept, trend and intercept and none included in test equation. The results of ADF test is presented in the following table.

TABLE No. 4.3

TABLE SHOWING ADF STATS FOR THE CHOSEN INDICES

\begin{tabular}{|c|c|c|c|c|c|}
\hline Indices & t-Statistic & Prob.* & Indices & t-Statistic & Prob.* \\
\hline Sensex & -13.07354 & 0.0000 & FCHI & -12.84361 & 0.0000 \\
\hline ATX & -10.38700 & 0.0000 & JKSE & -11.24974 & 0.0000 \\
\hline BEL20 & -10.87328 & 0.0000 & $\begin{array}{l}\text { ISEQ } \\
\end{array}$ & -11.56764 & 0.0000 \\
\hline Bo Vespa & -12.63258 & 0.0000 & Nikkei & -12.28044 & "0.0000 \\
\hline GSPTSE & -11.33152 & 0.0000 & MXX & -13.71305 & 0.0000 \\
\hline IPSA & -13.47032 & 0.0000 & IBEX & -13.71305 & 0.0000 \\
\hline$\overline{\text { SSEC }}$ & -12.69487 & 0.0000 & XU100.ES & -16.24456 & 0.0000 \\
\hline
\end{tabular}

It is evident from the above table that from the ADF test results we can reject the null hypothesis that there is a unit root in the time series data.

TABLE No. 4.4

TABLE SHOWING ADF STATS FOR THE INFLATION RATE

\begin{tabular}{||l||l||l||l||l||l||}
\hline \hline Country & t-Statistic & Prob. ${ }^{*}$ & Country & t-Statistic & Prob. $^{*}$ \\
\hline \hline India & -12.14910 & 0.0000 & France & -13.82685 & 0.0000 \\
\hline \hline Austria & -12.54701 & 0.0000 & Indonesia & -11.45282 & 0.0000 \\
\hline \hline Belgium & -7.275503 & 0.0000 & Ireland & -4.917515 & 0.0000 \\
\hline \hline Brazil & -6.152875 & 0.0000 & Japan & -5.788445 & 0.0000 \\
\hline \hline Canada & -6.941310 & 0.0000 & Mexico & -4.258922 & 0.0000 \\
\hline Chile & -6.077898 & 0.0000 & Spain & -9.081267 & 0.0000 \\
\hline \hline China & -6.133870 & 0.0000 & Turkey & -4.479842 & 0.0003 \\
\hline
\end{tabular}


However, in case of inflation we found unit root at level. When we 1 st differenced and $2^{\text {nd }}$ differenced the time series data they became stationary. Because of space constraint only first differenced results were shown.

TABLE No. 4.5

CORRELATION COEFFICIENT BETWEEN INFLATION AND INDEX RETURNS

\begin{tabular}{|c|c|c|c|c|c|}
\hline & Inflation & Prob.* & Country & t-Statistic & Prob.* \\
\hline Sensex & -0.024 & .727 & "FCHI & $-0.1785^{*}$ & .011 \\
\hline ATX & $-0.2649^{* *}$ & 2.000 & בJKSE & $-0.0178^{*}$ & 2.011 \\
\hline BEL20 & $-0.2841^{* *}$ & 2.000 & $\begin{array}{c}\text { ISEQ } \\
\end{array}$ & -.078 & .265 \\
\hline Bo Vespa & 0.0667 & .343 & Nikkei & $-.173^{*}$ & .013 \\
\hline $\begin{array}{l}\text { GSPTSE } \\
\text { GSTS }\end{array}$ & $-0.1861^{* * *}$ & ב.008 & MXX & -.013 & .856 \\
\hline IPSA & $-0.1705^{*}$ & 2.021 & IIBEX & -.083 & .238 \\
\hline$\overline{\text { SSEC }}$ & $-0.1971^{* * *}$ & 0.005 & XU100.ES & -.095 & .177 \\
\hline
\end{tabular}

In order to assess the relationship between the independent variable (Inflation) and dependent variable (Stock Index return) a correlation matrix has been constructed. The correlation between Sensex and Inflation was negative (-0.024) and statistically not significant. However, between ATX and inflation was negative $\left(-0.2649^{* *}\right)$ and significant. Between BEL20 and inflation was $-0.2841^{* *}$ and statistically significant. However in case of Brazil the relationship was positive 0.0667 and statistically not significant. In Canada both stocks and inflation share a significant relationship with a Pearson correlation coefficient of $-0.1861^{* *}$. In case of Chile, the correlation coefficient was $-0.1705^{*}$ which is statistically significant. Chinese stock market was also share a negative relationship with inflation with a correlation coefficient of $-0.1971^{* *}$. However, between FTHI and inflation the correlation coefficient was negative $-0.1785^{*}$ and significant. When it comes Indonesia it was significant and negative to $-0.0178^{*}$. In case of Ireland (ISEQ) the correlation coefficient was negative and not significant with a Pearson correlation coefficient of -.078. The correlation between Nikkei and Inflation was negative $\left(-.173^{*}\right)$ and statistically significant. In case of Mexico, the correlation coefficient was -.013 which is not statistically significant. Spain (IBEX) has recorded a negative correlation -.083 which is not statistically significant. Turkey has reported a negative correlation -.095 which is not statistically significant. All the chosen indices reported a negative relationship with inflation except France.

Table No 4.6

TABLE SHOWING REGRESSION RESULTS

\begin{tabular}{|c|c|c|c|c|}
\hline \multicolumn{5}{|c|}{ Austria } \\
\hline & Coefficients & Standard Error & $t$ Stat & $P$-value \\
\hline Intercept & 0.041205845 & 0.010281706 & 4.007685558 & $8.621 \mathrm{E}-05$ \\
\hline Inflation & -0.018933687 & 0.0048499 & -3.90393316 & 0.000128954 \\
\hline $\mathrm{R}^{2}$ & 0.070155797 & & Durbin-Watson & 1.852 \\
\hline \multicolumn{5}{|c|}{ Belgium } \\
\hline & Coefficients & Standard Error & t Stat & P-value \\
\hline Intercept & 0.023599217 & 0.006199 & 3.806963603 & 0.000186518 \\
\hline Inflation & -0.011078822 & 0.002631 & -4.211657634 & 0.000000 \\
\hline $\mathrm{R}^{2}$ & 0.080723658 & & Durbin-Watson & 1.786 \\
\hline \multicolumn{5}{|c|}{ Brazil } \\
\hline & Coefficients & Standard Error & $t$ Stat & $P$-value \\
\hline Intercept & -0.005349193 & 0.01395921 & -0.38320171 & 0.701973 \\
\hline Inflation & 0.001817627 & 0.00191348 & 0.949906213 & 0.343295 \\
\hline $\mathrm{R}^{2}$ & 0.004447075 & & Durbin-Watson & 1.783034 \\
\hline \multicolumn{5}{|c|}{ Canada } \\
\hline & Coefficients & Standard Error & t Stat & P-value \\
\hline Intercept & 0.018283935 & 0.006502887 & 2.811664261 & 0.005414335 \\
\hline
\end{tabular}


IRA-Intemational Journal of Management Eి Social Sciences

\begin{tabular}{|c|c|c|c|c|}
\hline Inflation & -0.00823508 & 0.003059306 & -2.691811951 & 0.007702487 \\
\hline $\mathrm{R}^{2}$ & 0.034628 & & Durbin-Watson & 1.622395 \\
\hline \multicolumn{5}{|c|}{ Chile } \\
\hline & Coefficients & Standard Error & t Stat & P-value \\
\hline Intercept & 0.019446272 & 0.005919856 & 3.284923255 & 0.001224817 \\
\hline Inflation & -0.003491624 & 0.001499631 & -2.328322482 & 0.021000035 \\
\hline$\overline{\mathrm{R}^{2}}$ & 0.029080 & & Durbin-Watson & 1.796285 \\
\hline \multicolumn{5}{|c|}{ China } \\
\hline & Coefficients & Standard Error & $t$ Stat & P-value \\
\hline Intercept & 0.019187038 & 0.008047169 & 2.384321459 & 0.018036166 \\
\hline Inflation & -0.007398949 & 0.00260178 & -2.843802524 & 0.00491628 \\
\hline $\mathrm{R}^{2}$ & 0.038495 & & Durbin-Watson & 1.852157 \\
\hline \multicolumn{5}{|c|}{ France } \\
\hline & Coefficients & Standard Error & $t$ Stat & $P$-value \\
\hline Intercept & 0.0143009 & 0.00696835 & 2.052264931 & 0.041433513 \\
\hline Inflation & -0.010723356 & 0.004159691 & -2.577921159 & 0.010651356 \\
\hline $\mathrm{R}^{2}$ & 0.031851 & & Durbin-Watson & 1.856372 \\
\hline \multicolumn{5}{|c|}{ Indonesia } \\
\hline & Coefficients & Standard Error & $t$ Stat & $P$-value \\
\hline Intercept & 0.022660654 & 0.010220153 & 2.21725187 & 0.027720757 \\
\hline Inflation & -0.001415768 & 0.001265406 & -1.118825104 & 0.264543454 \\
\hline $\mathrm{R}^{2}$ & 0.006159 & & Durbin-Watson & 1.545740 \\
\hline \multicolumn{5}{|c|}{ Ireland } \\
\hline & Coefficients & Standard Error & $t$ Stat & $P$-value \\
\hline Intercept & 0.008667964 & 0.005068738 & 1.710083042 & 0.08878596 \\
\hline Inflation & -0.003762867 & 0.00150508 & -2.500110924 & 0.013211111 \\
\hline $\mathrm{R}^{2}$ & 0.030015 & & Durbin-Watson & 1.634812 \\
\hline \multicolumn{5}{|c|}{ Japan } \\
\hline & Coefficients & Standard Error & $t$ Stat & $P$-value \\
\hline Intercept & 0.000811317 & 0.004002959 & 0.202679203 & 0.839589776 \\
\hline Inflation & -0.000688074 & 0.00378418 & -0.18182913 & 0.855899155 \\
\hline $\mathrm{R}^{2}$ & 0.000164 & & $\begin{array}{l}\text { Durbin-Watson } \\
\end{array}$ & 1.713962 \\
\hline \multicolumn{5}{|c|}{ Mexico } \\
\hline & Coefficients & Standard Error & t Stat & $P$-value \\
\hline Intercept & 0.023039101 & 0.011782162 & 1.955422173 & 0.051905675 \\
\hline Inflation & -0.002968821 & 0.002509446 & -1.183058241 & 0.238169737 \\
\hline $\mathrm{R}^{2}$ & 0.006848 & & Durbin-Watson & 1.925535 \\
\hline \multicolumn{5}{|c|}{ Spain } \\
\hline & Coefficients & Standard Error & $t$ Stat & $P$-value \\
\hline Intercept & 0.006988155 & 0.006837791 & 1.021990063 & 0.308007984 \\
\hline inflation & -0.003362056 & 0.002481788 & -1.354690812 & 0.177029299 \\
\hline $\mathrm{R}^{2}$ & 0.009003 & & Durbin-Watson & 1.887351 \\
\hline \multicolumn{5}{|c|}{$\begin{array}{l}\text { Turkey } \\
\end{array}$} \\
\hline & Coefficients & Standard Error & t Stat & P-value \\
\hline Intercept & 0.01731645 & 0.010004476 & 1.730870271 & 0.085002 \\
\hline inflation & -0.000612613 & 0.000434663 & $\begin{array}{l}-1.409397748 \\
\end{array}$ & 0.160255 \\
\hline $\mathrm{R}^{2}$ & 0.009738 & & Durbin-Watson & 2.081110 \\
\hline
\end{tabular}

Analysis: Intercept is $\alpha$ in the set equation. Standard error measures the variability in approximation of the coefficient and lower standard error means coefficient is closer to the true value of coefficient. R square represents the percentage movement of the dependent variable which is captured by the intercept and the independent variable. Above obtained results explain $00.0600 \%$ of the variation in Index return was captured by independent variable (Inflation). Where Durbin-Watson score is 1.847 . 


\section{Test of Hypothesis}

\section{Austria}

Result shows that independent variable (Inflation)share negative coefficient with the dependent variable meaning that inflation shares an inverse relationship with the dependent variable (stock returns). Inflation is statistically significant at 0.01 level with a p value of 0.000128954 therefore we can reject the Null hypothesis. With an R square value of $7.02 \%$ and Where Durbin-Watson value of 1.852 .

\section{Belgium}

Result shows that independent variable (Inflation)share negative coefficient with the dependent variable meaning that it shares an inverse relationship with the dependent variable (stock returns). Inflation is statistically significant at 0.01 level with a p value of 0.000000 therefore we can reject the Null hypothesis. With an $\mathrm{R}$ square value of $7.02 \%$ and Where Durbin-Watson value of 1.852 .

\section{Brazil}

Regression result shows that independent variable (Inflation)share positive coefficient with the dependent variable meaning that it shares an direct relationship with the dependent variable (stock returns). Inflation is statistically not significant at 0.05 level with a p value of 0.343295 therefore we cannot reject the Null hypothesis. Where R square value of $0.445 \%$ and Where Durbin-Watson value of 1.783034 .

\section{Canada}

Result shows that the predictor (Inflation)share negative coefficient with the dependent variable meaning that it shares an inverse relationship with the dependent variable (stock returns). Inflation is statistically significant at 0.01 level with a p value of 0.007702487 therefore we can reject the Null hypothesis. With an R square value of $0.770 \%$ and Where Durbin-Watson value of 1.622395 .

\section{Chile}

Result shows that the predictor (Inflation)share negative coefficient with the dependent variable meaning that it shares an inverse relationship with the dependent variable (stock returns). Inflation is statistically significant at 0.05 level with a $\mathrm{p}$ value of 0.021000035 therefore we can reject the Null hypothesis. With an $\mathrm{R}$ square value of $2.908 \%$ and Where Durbin-Watson value of 1.796285 .

\section{China}

Result shows that the predictor (Inflation)share negative coefficient with the dependent variable meaning that it shares an inverse relationship with the dependent variable (stock returns). Inflation is statistically significant at 0.01 level with a p value of 0.00491628 therefore we can reject the Null hypothesis. With an R square value of $3.850 \%$ and Where Durbin-Watson value of 1.852157 .

\section{France}

Result shows that the predictor (Inflation)share negative coefficient with the dependent variable meaning that it shares an inverse relationship with the dependent variable (stock returns). Inflation is statistically significant at 0.05 level with a $\mathrm{p}$ value of 0.010651356 therefore we can reject the Null hypothesis. With an R square value of $3.185 \%$ and Where Durbin-Watson value of 1.856372 .

\section{Indonesia}

Regression result shows that independent variable (Inflation)share positive coefficient with the dependent variable meaning that it shares an direct relationship with the dependent variable (stock returns). Inflation is statistically not significant at 0.05 level with a p value of 0.264543454 therefore we cannot reject the Null hypothesis. Where R square value of $0.616 \%$ and Where Durbin-Watson value of 1.545740 .

\section{Ireland}

Result shows that the predictor (Inflation)share negative coefficient with the dependent variable meaning that it shares an inverse relationship with the dependent variable (stock returns). Inflation is statistically significant at 0.05 level with a $\mathrm{p}$ value of 0.013211111 therefore we can reject the Null hypothesis. With an $\mathrm{R}$ square value of $3.002 \%$ and Where Durbin-Watson value of 1.634812 .

\section{Japan}

Regression result shows that independent variable (Inflation)share positive coefficient with the dependent variable meaning that it shares an direct relationship with the dependent variable (stock returns). Inflation is 
statistically not significant at 0.05 level with a p value of 0.855899155 therefore we cannot reject the Null hypothesis. Where R square value of $0.0164 \%$ and Where Durbin-Watson value of 1.713962 .

\section{Mexico}

Regression result shows that independent variable (Inflation)share positive coefficient with the dependent variable meaning that it shares an direct relationship with the dependent variable (stock returns). Inflation is statistically not significant at 0.05 level with a p value of 0.238169737 therefore we cannot reject the Null hypothesis. Where R square value of $0.6848 \%$ and Where Durbin-Watson value of 1.925535 .

\section{Spain}

Regression result shows that independent variable (Inflation)share positive coefficient with the dependent variable meaning that it shares an direct relationship with the dependent variable (stock returns). Inflation is statistically not significant at 0.05 level with a p value of 0.177029299 therefore we cannot reject the Null hypothesis. Where R square value of $0.900 \%$ and Where Durbin-Watson value of 1.887351 .

\section{Turkey}

Regression result shows that independent variable (Inflation)share positive coefficient with the dependent variable meaning that it shares an direct relationship with the dependent variable (stock returns). Inflation is statistically not significant at 0.05 level with a $\mathrm{p}$ value of 0.160255 therefore we cannot reject the Null hypothesis. Where R square value of $0.974 \%$ and Where Durbin-Watson value of 2.081110 .

\section{RESIDUAL DIAGNOSTICS}

Table No 4.7

\begin{tabular}{||l||l||l||l||l||l||l||l||}
\hline \multicolumn{3}{||l||l||l||l||}{ Breusch-Godfrey Serial Correlation LM Test } & \multicolumn{3}{l||}{ Heterkedasticity Test: Breusch-Pagan-Godfrey } \\
\hline \hline F-statistic & Prob. F & Obs*R-Sq & Prob. & F-statistic & Prob. F & Obs*R-square & Prob. \\
\hline \hline 0.195741 & 0.8224 & 0.400485 & 0.8185 & 0.143455 & 0.8664 & 0.290759 & 0.8647 \\
\hline \hline 0.282054 & 0.7545 & 0.576710 & 0.7495 & 0.243461 & 0.6694 & 0.340369 & 0.7664 \\
\hline \hline 1.505278 & 0.2245 & 3.040352 & 0.2187 & 1.163613 & 0.3717 & 2.241414 & 0.3116 \\
\hline \hline 1.083646 & 0.3404 & 2.197964 & 0.3332 & 2.076946 & 0.1280 & 4.130413 & 0.1268 \\
\hline \hline 0.800580 & 0.4505 & 1.628424 & 0.4430 & 1.066603 & 0.3464 & 2.143413 & 0.3424 \\
\hline \hline 0.998833 & 0.3704 & 2.031174 & 0.3622 & 0.241454 & 0.7163 & 0.391219 & 0.7131 \\
\hline \hline 1.409628 & 0.2470 & 2.853446 & 0.2401 & 2.790496 & 0.0641 & 5.502953 & 0.0638 \\
\hline \hline 0.829119 & 0.4379 & 1.685993 & 0.4304 & 0.797145 & 0.3913 & 1.557191 & 0.5816 \\
\hline \hline 0.580782 & 0.5604 & 1.183951 & 0.5532 & 1.897523 & 0.0719 & 5.039181 & 0.0719 \\
\hline \hline 0.686938 & 0.5043 & 1.398863 & 0.4969 & 0.815838 & 0.4437 & 1.642749 & 0.4398 \\
\hline \hline 0.545497 & 0.5804 & 1.112414 & 0.5734 & 0.899631 & 0.43180 & 4.113811 & 0.4051 \\
\hline \hline 0.832315 & 0.4365 & 1.692300 & 0.4291 & 0.732326 & 0.4171 & 1.793310 & 0.3962 \\
\hline \hline 1.650056 & 0.1947 & 3.327981 & 0.1894 & 1.553021 & 0.1743 & 3.417582 & 0.1793 \\
\hline \hline 0.270908 & 0.7630 & 0.553982 & 0.7581 & 0.371901 & 0.7210 & 0.573081 & 0.7234 \\
\hline \hline
\end{tabular}

In order to investigate the existence of serial correlation in the time series data, B-G Serial correlation LM test has been conducted. It is evident from the above table that the there is no serial correlation in the time series data. In the second phase, we conducted Breusch-Pagan-Godfrey heteroskedasticity test It is evident from the above table that there is no Heteroskedasticity in the time series data. 
Exhibit 4.1

CUSUM test
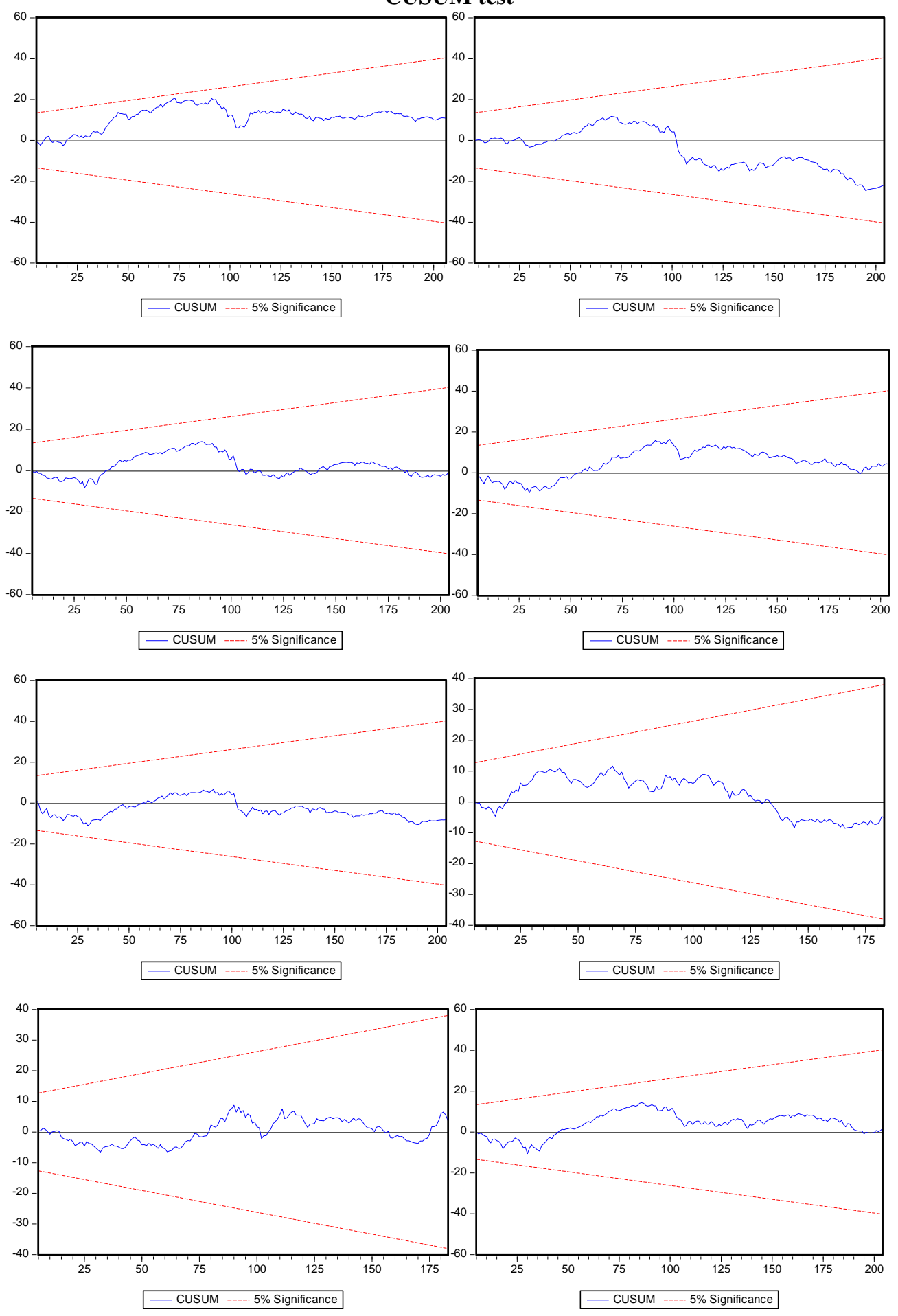

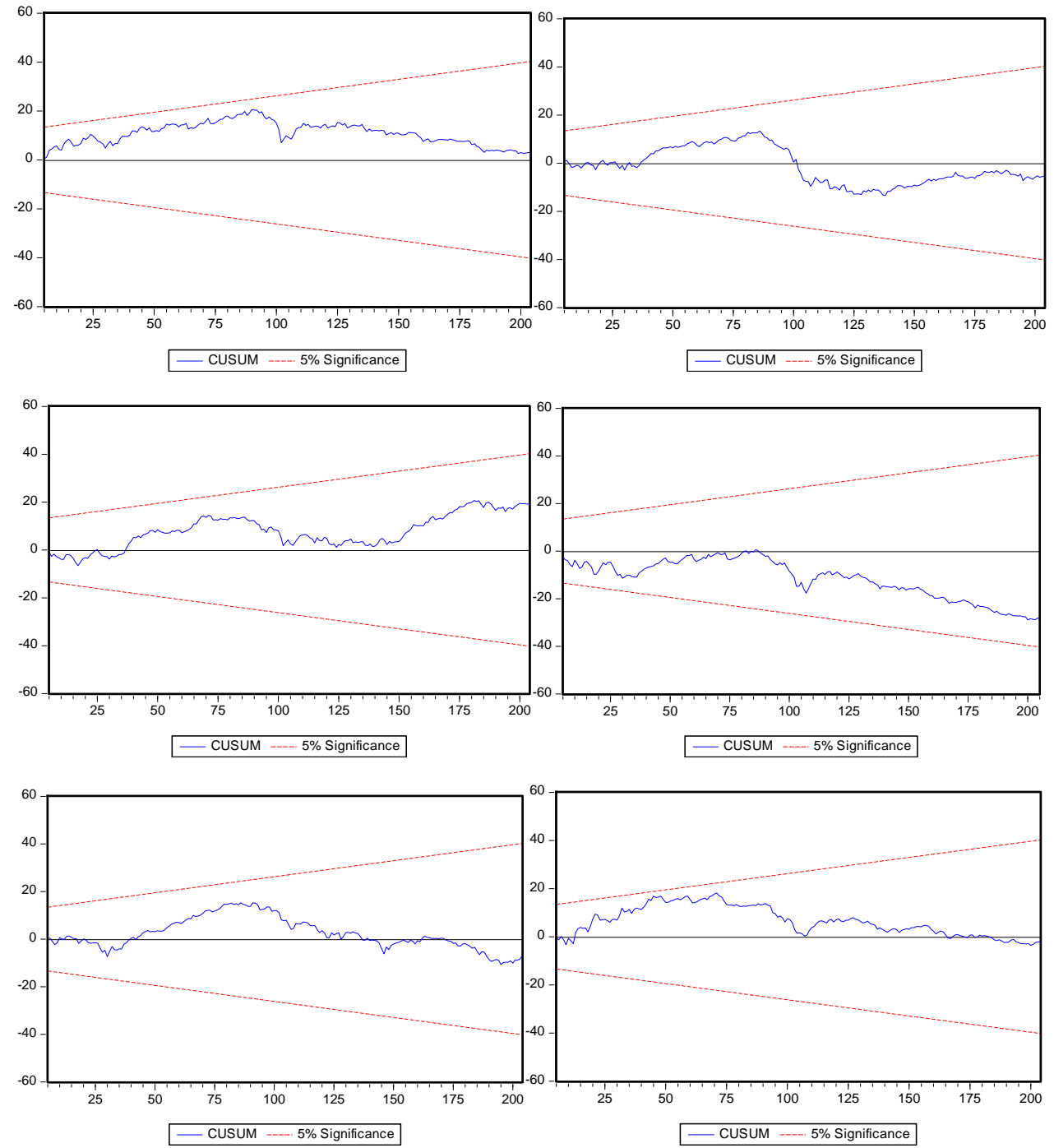

CUSUM test is based on the cumulative sum of the equation errors in regression. Views graphically represents the cumulative sum of errors together with critical lines of 5\%. The equation parameters are not treated stable if the whole sum of recursive errors goes beyond the two critical bands. It is evident from the above Exhibit 1 that the stability of the regression model was good.

TABLE No. 4.8

JOHANSEN COINTEGRATION TEST (SENSEX)

\begin{tabular}{|c|c|c|c|c|}
\hline \multicolumn{5}{|c|}{ India } \\
\hline \multicolumn{5}{|c|}{ Unrestricted Cointegration Rank Test (Trace) } \\
\hline $\begin{array}{l}\text { Hypothesized } \\
\text { No. of CE(s) } \\
\end{array}$ & Eigenvalue & $\begin{array}{c}\text { Trace } \\
\text { Statistic } \\
\end{array}$ & $\begin{array}{c}0.05 \\
\text { Critical Value } \\
\end{array}$ & Prob. $* *$ \\
\hline None * & 0.141878 & 33.70920 & 15.49471 & 0.0000 \\
\hline At most 1 & 0.014591 & 2.954346 & 3.841466 & 0.0856 \\
\hline \multicolumn{5}{|c|}{ Unrestricted Cointegration Rank Test (Maximum Eigenvalue) } \\
\hline $\begin{array}{l}\text { Hypothesized } \\
\text { No. of CE(s) }\end{array}$ & Eigenvalue & $\begin{array}{l}\text { Max-Eigen } \\
\text { Statistic }\end{array}$ & $\begin{array}{c}0.05 \\
\text { Critical Value }\end{array}$ & Prob.** \\
\hline None * & 0.141878 & 30.75486 & 14.26460 & 0.0001 \\
\hline At most 1 & 0.014591 & 2.954346 & 3.841466 & 0.0856 \\
\hline \multicolumn{5}{|c|}{ Normalized cointegrating coefficients } \\
\hline Coefficient & -0.000133 & & Standard Error & $(0.00205)$ \\
\hline
\end{tabular}


Trace test indicates 2 cointegrating eqn(s) at the 0.05 level

$*$ denotes rejection of the hypothesis at the 0.05 level

Analysis: In the last phase we conducted Johansen Cointegration test to identify any possible equilibrium between inflation and Index return (India). The above table No.4.8 presents the results for trace test and maximum Eigenvalue test. Trace statistics states that there is at least one co integrated equation or the variables were co integrated. Maximum eigenvalue test results indicate at most one co integrated equation or the variables were co integrated. The test results indicate that the monthly data chosen for the purpose of the study there exists a long term association between inflation rate and stock returns. The results indicates that there is a co integration between the two variables - meaning that there is one error term in the model. Both Trace and Max Eigen value are telling that there is a long run association ship.

Now we can run the VECM because the variables are cointegrated.

Table No 4.9

Table showing Error Correction Model

\begin{tabular}{|c||r|r||r||r||}
\hline & Coefficient & Std. Error & t-Statistic & Prob. \\
\hline \hline $\mathrm{C}(1)$ & -0.859270 & 0.153505 & -5.597648 & 0.0000 \\
\hline $\mathrm{C}(2)$ & -0.053169 & 0.142947 & -0.371952 & 0.7103 \\
\hline $\mathrm{C}(3)$ & -0.063038 & 0.132533 & -0.475641 & 0.6349 \\
\hline $\mathrm{C}(4)$ & 0.022921 & 0.117209 & 0.195560 & 0.8452 \\
\hline $\mathrm{C}(5)$ & 0.096955 & 0.097590 & 0.993488 & 0.3217 \\
\hline $\mathrm{C}(6)$ & 0.061986 & 0.071539 & 0.866462 & 0.3873 \\
\hline $\mathrm{C}(7)$ & -0.004540 & 0.006015 & -0.754750 & 0.4513 \\
\hline $\mathrm{C}(8)$ & -0.007654 & 0.006042 & -1.266779 & 0.2068 \\
\hline $\mathrm{C}(9)$ & 0.006237 & 0.006092 & 1.023817 & 0.3072 \\
\hline $\mathrm{C}(10)$ & 0.002351 & 0.006057 & 0.388067 & 0.6984 \\
\hline $\mathrm{C}(11)$ & -0.005729 & 0.005430 & -1.055065 & 0.2927 \\
\hline $\mathrm{C}(12)$ & 0.000501 & 0.004753 & 0.105328 & 0.9162 \\
\hline \hline
\end{tabular}

$\mathrm{C}(1)$ is the residual of the 1 period lag residual of the cointegrating vector between Inflation and Index returns that means between the Index returns (dependent) and inflation is the independent variable. In this case, the $\mathrm{C}$ (1) is negative and p value is also significant. Error correction term is significant and sign is minus it means that Inflation has a long run causality from inflation to index returns.

In order to assess the short run relationship or the short run causality from inflation to index returns. For this purpose we have used the chi square value of Wald statistics to check the short run causality here inflation

Table 4. 10

Wald Test

\begin{tabular}{|l||c||c|c||}
\hline Test Statistic & Value & df & Probability \\
\hline F-statistic & 0.946630 & $(5,188)$ & 0.4521 \\
\hline Chi-square & 4.733149 & 5 & 0.4493 \\
\hline
\end{tabular}

It is evident from the above table that there is no short rum causality model from inflation to index returns.

Conclusion: There is a long run causality model from Inflation to index returns, however, there is no short run causality Inflation to index returns based on Wald statistics.

\section{Model specification}

Table No. 4.11

1. Breusch-Godfrey Serial Correlation LM Test

\begin{tabular}{|c|c|c|c|}
\hline F-statistic & 0.629303 & Prob. F(2,186) & 0.5341 \\
\hline Obs*R-squared & 1.344244 & Prob. Chi-Square(2) & 0.5106 \\
\hline
\end{tabular}

In order to investigate the serial correlation in the constructed model, B-G Serial correlation LM test has been conducted with the following hypothesis $\mathrm{H}_{0}: \rho=0$. It is clear from the above table that there is no serial correlation in the constructed model. 
Table No. 4.12

Heteroskedasticity Test: ARCH

\begin{tabular}{|c|c|c|c|}
\hline F-statistic & 0.209272 & Prob. F(2,195) & 0.8114 \\
\hline Obs*R-squared & 0.424072 & Prob. Chi-Square(2) & 0.8089 \\
\hline
\end{tabular}

One of the major assumption of time series distribution is that there is heteroskedasticity in the data. It means that if the variance of $e_{i}$ is same for all the data points in the time series data then it is said to be Homoskedastic distribution. Therefore, we have conducted Breusch-Pagan-Godfrey test for the existence of heteroskedasticity in the distribution. It is clear from the above table that there is no heteroskedasticity in the computed model.

Table No. 4.13

\section{NORMALITY TEST}

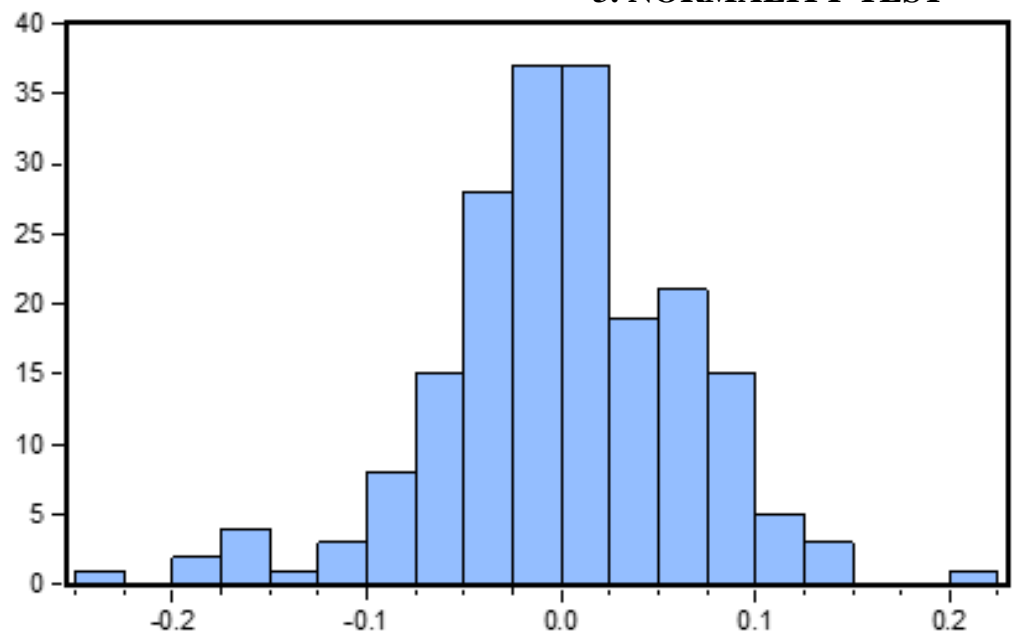

Series: Residuals Sample 10/31/20004/02/2017 Observations 200

Mean

$8.15 e-19$

Median $\quad 0.000830$

Maximum $\quad 0.214860$

Minimum $\quad-0.248730$

Std. Dev. $\quad 0.065284$

Skewness $\quad-0.335151$

Kurtosis $\quad 3.308546$

Jarque-Bera $\quad 0.567194$

Probability $\quad 0.753070$

In order to investigate the normality of the distribution Jarque-Bera test for normality has been conducted. It is evident from the above table that the data is normally distributed.

\section{DISCUSSION AND CONCLUSION}

The current paper entitled "relationship between inflation and stock market evidence from selected global stock markets" have been undertaken with an intention to investigate the relationship between inflation and stock returns of the chosen economies. In order to realise the stated objectives the researchers have collected the monthly data from 1.3.2000 to 31-03-2017. In the first phase we conducted ADF test to investigate the existence of unit root in the distribution. In the second phase we ran Pearson correlation coefficient for the collected data to find out the association between the inflation and stock returns. We found a significant relationship between inflation and stock returns for Austrian index (ATX), Belgium Index (BEL20), Canadian Index (GSPTSE), Chile Index (IPSA), Chinese Index (SSEC), France Index (FTHI), Indonesian Index (JKSE) and Japanese Index (Nikkei) with negative relationship. However, for Ireland (ISEQ), Mexico (MXX), Spain (IBEX) and Turkey (XU100.ES) we found a negative correlation coefficient without any statistically significant relationship. For Brazilian Index (Bo Vespa) we found a positive correlation coefficient and statically insignificant relationship. In the next phase we ran linear regression and found the following findings: For Austria, inflation was statistically significant at one percent with negative coefficient. For Belgium we found a negative coefficient and it was statistically significant at one percent level. However, Brazil had a positive coefficient with the dependent variable and Inflation was statistically not significant. For Canada the predictor was sharing negative coefficient and was statistically significant at one percent level. For Chile Inflation shares negative coefficient and was statistically significant at five percent. In China the predictor has shared a negative coefficient and was statistically significant at one percent level. However, France the predictor shared a negative coefficient with the dependent variable (stock returns). Inflation was statistically significant at five percent level. In Indonesian economy the independent variable (Inflation) shared positive coefficient with the dependent variable. Inflation was statistically not significant at five percent level. For Ireland the Inflation shared a negative coefficient with the dependent variable and it was statistically significant at five percent level. In Japanese economy the independent variable had a positive coefficient with the dependent variable however, Inflation is statistically not significant at conventional level. Mexico has reported a positive coefficient and was statistically not significant whereas, we found a positive coefficient in Spanish economy and it was statistically not significant. For Turkey, we found a positive coefficient with the dependent variable and it was not statistically not significant at 
conventional level. For Indian benchmark index, we found a long run causality model from Inflation to index returns, however, there is no short run causality Inflation to index returns based on Wald statistics.

History has demonstrated that high inflation can affect the economy in so many ways for example, it erodes the purchasing power of currency. It discourages investment, reduces the value of savings, high inflation leads to fall in real wages. It affects all the segments of the nation. Our results are in line with the literature for example, Zhao (1999); Bethlehem (1972); Bakshi and Chen (1996); Spyrou (2001); Rao and Bhole (1990) etc.

Current study clearly throws light on the effect of inflation on the stock market returns therefore, it can help the market participants such as traders, fund managers, financial market regulators and investors to make good portfolio decisions based on the information about expected inflation and unexpected inflation. The study confirms that there exists an inverse relationship between the stock market returns and inflation firms can take this one has a clue to adjust their reported profits by raising the prices.

Even the policy makers can also take the current findings has a clue to frame prudent monetary policies to regulate the inflationary trends in the economy. It is suggested to the policy makers to have a contractionary policy to reduce the supply of money by offering low interest rate on t bills, increasing the interest rates (bank rate policy) and increasing the cash reserve ratios which in turn reduces the lending capacity of the banks. In the process, it freezes the further acceleration in prices to the extent it is created by banks credit to the public. From the above policy, one can effectively control the inflation. For any economy this is vital because, reducing spending is during inflationary trends regulates the rate of inflation.

As for as economics is concerned, inflation is an outcome of mismatch in demand and supply sides meaning that failure of aggregate supply to match the escalation in aggregate demand. Therefore, inflation can be regulated by increasing the supply of necessary goods and services. Most of the time the monetary policy of the state alone, may not be effective in regulating inflation, for example if it is due to cost-push factors. In general monetary policy can check the inflation due to demand-pull factors. The economists suggest that a nation can achieve higher growth by regulating the rate of inflation and raising public investment. To achieve the growth and maintain lower inflation, the state needs to control budget deficits.

Yet another important measure to regulate inflation is currency demonetisation especially higher denominations. This is a very effective measure only when there is myriad of black money in the economy. Monetary policy alone is inadequate of regulating inflation. It should, therefore, be strengthened by proactive fiscal policy. In this case inflation can be regulated by controlling the unnecessary government and public expenditure. This can be achieved through, effective taxing policy by providing incentive to those who save and penalising the evaders by imposing fines. In the background of the current empirical study, the statistical relationship between the rate of inflation and its impact on stock market depending on the nation's monetary and fiscal policy, the methodology and the basket of commodities and services used and the period of study among other factors. The findings of the study confirms the theory that inflation in an economy has a negative impact on the performance of stock market. Through, effective monetary and fiscal policies the government can check the rate of inflation and thus creating investors' confidence in the capital market. Further, there is a great need to identify factors such as growth rate, GDP, inflation, interest rate, oil shocks etc. that have significant effect on stock market performance. This will facilitate investors and capital market regulators to make rational decisions.

\section{REFERENCES}

[1] Abdullah, D. A. and Hayworth, S. C., (1993). "Macroeconomics of stock price fluctuations". Quarterly Journal of Business and Economics; 32(1): 49-63.

[2] Aggarwal, R. (1981). "Exchange rate and stock prices. A Study of US Capital Markets Under Floating Exchange Rates", Akron Business and Economic Review, 12(2): 7-12.

[3] Ahmed, S. (2008). "Aggregate Economic Variables and Stock Markets in India", International Research Journal of Finance and Economics, 14.

[4] Akinifesi O (1987). "The Role and Performance of the Capital market in Adedotun Philips and Eddy Ndekwu (eds) Economic Policy and Development in Nigeria NISER", Ibadan Nigeria.

[5] Akmal, M.S. (2007)."Stock returns and inflation: An ARDL econometric investigation utilizing Pakistani data".Pakistan Economic and Social Review. Volume 45(1), pp. 89-105.

[6] Bacon, R., M., Kojima. (2008). "Vulnerability to oil price increases. A decomposition analysis of 161 countries". World Bank Extractive Industries and Development Series \#1.

[7] Bacon, Robert; Kojima, Masami. (2008). "Oil Price Risks. Viewpoint: Public Policy for the Private Sector"; Note No. 320. World Bank, Washington, DC. (C) World Bank. https://openknowledge.worldbank.org/handle/10986/11151 License: CC BY 3.0 IGO." 
[8] Bahmani-Oskooee, M. and Sohrabian, A. (1992), "Stock prices and the effective exchange rate of the dollar", Applied Economics, 24 (4), pp. 459-64.

[9] Bakshi, G. S. \& Chen, Z. (1996). "Inflation, Asset Prices, and the Term Structure of Interest Rates in Monetary Economies". Review of FinancialStudies, 9, pp. 241-275.

[10] Barro R. (1995) "Inflation and Economic Growth", Federal Reserve Bank of St. Louis Review, Vol. 78, pp. 153169.

[11] Barro, R J (1995): "Inflation and Economic Growth”, Bank of England Quarterly Bulletin, May.

[12] Bethlehem, G. (1972).“An Investigation of the Return on Ordinary Share Quoted on the Johannesburg Stock Exchange with Reference to Hedging Against Inflation”, South African Journal of Economics, 40(3), pp. 254 -257.

[13] Bhattacharya, B, Mukherjee, J. (2002). "The Nature of The Casual Relationship between Stock Market and Macroeconomic Aggregates in India: An Empirical Analysis", Paper presented in the 4th Annual Conference on Money and Finance, Mumbai, India.

[14] Bodie, Z. (1976), “Common Stocks as a Hedge against Inflation” Journal of Finance, Vol. 31, pp. 459- 470.

[15] Bohl MT, Siklos PL, Werner T (2007). "Do central banks react to the stock market? The case of the Bundesbank", Journalof Bank. Finance.31: pp. 719-33.

[16] Boudhouch and Richarson, (1993). "Stock returns and inflation: a long-horizon perspective". American Economic Review, pp. 1346-1355.

[17] Boyd, John H. Levine, Ross, and Smith, Bruce D. (1996). "Inflation and Financial Market performance", Federal Reserve Bank of Minneapolis Research Department, Working Paper. 573D.

[18] Boyd, John H. Levine, Ross, and Smith, Bruce D. (2001). "The impact of inflation on financial market performance". Journal of Monetary Economics, 47, pp. 221-248

[19] Bruno, M. and Easterly, W. (1996) "Inflation Crises and Long-Run Growth", Review of Federal Reserve Bank of St. Louis, Vol. 78, no. 3, pp. 139-46.

[20] Caporale and Jung (1997) attempted to investigate the causal relationship between both expected and unexpected inflation and real stock prices, and documented a positive relationship.

[21] Caporale, T. \& Jung, C. (1997). Inflation and Real Stock Prices. Applied Financial Economics, 7, 265-266.

[22] Chaudhuri, K. and S. Smile, (2004), "Stock market and aggregate economic activity: evidence from Australia", Applied Financial Economics, 14, 121-129.

[23] Cheng ACS (1995). "The UK Stock Market and Economic Factors: A New Approach", J. Bus. Financ. Account.22, pp. 129-142.

[24] Choudhry, T. (2001). “Inflation and Rates of Return on Stocks: Evidence from High Inflation Countries”, Journal of International Financial Markets, Institutions and Money, 11: pp. 75-76.

[25] Darrat, A. F. (1990). "Stock Returns, Money and Fiscal Deficits", Journal of Financial and Quantitative Analysis 25, 387-398.

[26] David A. Marshall (1992). "Inflation and Asset Returns in a Monetary Economy". The Journal of Finance. Volume 47, Issue 4, pp. 1315-1342, September.

[27] DeFina, R.H., (1991), "Does inflation depress the stock market", Federal Reserve Bank of Philadelphia Business Review, Nov., 3-12.

[28] Dickey, D. A. \& Fuller, W. A. (1979). "Distribution of Estimators of Autoregressive Time Series with a Unit Root". Journal of the American Statistical Association, 74: 427-431.

[29] Engle RF, Granger CWJ (1987) "Co-integration and error correction: representation, estimation and testing", Econometrica, Vol. 55, pp. 251-276.

[30] English, W.B. (1999), "Inflation and Financial sector Size.” Journal of Monetary Economics 44, pp. 379-400

[31] Fama, E. F. (1981), "Stock Returns, Real Activity, Inflation and Money" American Economic Review, Vol. 71, 545-565.

[32] Fama, E. F. and G. W. Schwert, (1977), "Asset Returns and Inflation” Journal of Financial Economics, Vol. 5, $115-146$.

[33] Fama, E. F. and K. R. French (1989). "Business Conditions and Expected Returns on Stocks and Bonds" Journal of Financial Economics 25, pp. 23-49.

[34] Fama, E. F., 1981. Stock returns, real activity, inflation, and money. The American Economic Review; 71: pp. 545-565.

[35] Fama, E. F., 1981. Stock returns, real activity, inflation, and money. The American Economic Review; 71: pp. 545-565.

[36] Fama, F. \& Schwert, G. (1977). “Assets returns and inflation”. Journal of Financial Economics, 5, pp. 115-146.

[37] Fang, W. and Miller,SM. (2002). "Currency Depreciation and Korean Stock Market Performance during the Asian Financial Crisis". Working Paper 2002-30, University of Connecticut.

[38] Feldstein, M. (1980), "Inflation and the Stock Markets".American Economic Review, Vol. 70, pp. 839-847.

[39] Firth, (1979). "The relationship between stock market returns and rates of inflation". Journal of Finance, pp. 743749.

[40] Fischer S. (1993) “The Role of Macroeconomic Factors in Growth”, Journal of Monetary Economics, Vol. 32, pp. 45-66.

[41] Fisher, I. (1930). "The Theory of Interest”, New York: MacMillan.

[42] Geetha, C,.Mohidin, R,.Chandran,VV. and Chong,V. (2011). "The relationship between inflation and stockmarket: evidence from Malaysia, United States and China". International Journal of Economics and Management Sciences, 1(2): 01-16.

[43] Ghosh A. and Phillips S. (1998) "Warning: Inflation May be Harmful to Your Growth”, IMF Staff Papers, Vol. 45, pp. $672-710$ 
[44] Gultekin, N.B. (1983).“Stock Market Returns and Inflation: Evidence from Other Countries”, Journal of Finance, 38(1): pp. 49-65.

[45] Haslag, J. and Koo, J. (1999), "Financial Repression, Financial Development and Economic Growth." Federal Reserve Bank of Dallas Working Paper 99-102.

[46] Huang, R. D. and Kracaw, W. A. (1984). "Stock market Returns and Real Activity: A note". Journal of Finance, 39: pp. 267-72.

[47] Huang, R. D. and Kracaw, W. A., (1984). "Stock market returns and real activity: a note". Journal of Finance; 39: pp. 267-273.

[48] Ioannides, D., Katrakilidis, C. and Lake, A. (2005).“The Relationship Between Stock Market Returns and Inflation: An Econometric Investigation Using Greek Data", Paper Presented at the International Symposium on Applied Stochastic Models and Data Analysis, Brest-France, 17-20 May.

[49] Jaffe, J. F, and G. Mandelker. (1976). "The Fisher effect" for risky assets: An empirical investigation".Journal of Finance. 31, pp. 447-458.

[50] Jain PC (1988). "Response of hourly stock prices and trading volume to economic news", J. Bus., 61: pp. $219-231$.

[51] Johansen (1990). "Maximum likelihood and inference on cointegration with applications to the demand for money" Oxford Bulletin of Economics and Statistics, 52: 169- 210.

[52] K. V. S. S. Narayana Rao and L. M. Bhole (1990). "Inflation and Equity Returns, "Economic and Political Weekly", Vol. 25, No. 21 (May), pp. M91-M96.

[53] Kessel, R.A., (1956), "Inflation caused wealth redistribution: A test of a hypothesis", American Economic Review 46, pp. 128-141.

[54] Lintner, J. (1975), "Inflation and Security Returns" Journal of Finance, Vol. 30, pp. 259-280.

[55] Nelson C. R. (1976). "Inflation and rates of return on common stocks". Journal of Finance, 31: pp. 471-483.

[56] Nissim D, Penman SH (2003). "The Association between Changes in Interest Rates, Earnings, and Equity Values", Contemporary Account. Res., 20 (4): pp. 775-804.

[57] Pilinkus, D. and Boguslauskas, V., (2009), "The Short-run relationship between stock market prices and macroeconomic variables in Lithuania: an application of the impulse response function", Inzinerine EkonomikaEngineering Economics, Economics of Engineering Decisions, 5, pp. 1-9.

[58] Rangarajan, C (1998): "Development, Inflation and Monetary Policy" in I S Ahluwalia and I M D Little (eds), India's Economic Reforms and Development, Oxford University Press.

[59] Rao Narayana K V S S \& Bhole L M (1990), "Inflation and Equity Returns", Economic \& Political Weekly, Vol. 25, No. 21, May 26, p. M 91-96.

[60] Robert, D.G. (2008), "Effect of Macroeconomic Variables on Stock Market Returns for four Emerging Economies: Brazil, Russia, India and China", International Business \& Economics Research Journal, Vol.7 (3), pp. 1-8.

[61] Roger D. Huang, William A. Kracaw (1984). "Stock Market Returns and Real Activity: A Note". The Journal of Finance. Volume 39, Issue 1, March, pp. 267-273

[62] Rousseau, P. L., Wachtel, P.,(2002); "Inflation Thresholds and the Finance-Growth nexus", Journal of International Money and Finance 21, 777-793

[63] Samarakoon, L. P. (1996)."Stock Market Returns and Inflation: Sri Lankan Evidence”. Sri Lankan Journal of Management, 1(4): 293-311, 1996. Available SSRN:http://ssrn.com/abstract=1395015.

[64] Sarel, M. (1996). "Nonlinear effects of inflation on economic growth". IMF Working Staff Papers, 43(1), pp. 199215.

[65] Schwert GW (1990). “Alternative models for conditional stock volatility”, J. Econ., 45: pp. 267-290.

[66] Soenen LA, Hennigar ES (1988). "An analysis of exchange rates and stock prices: The US experience between 1980 and 1986”. Akron Bus. Econ. Rev., 19: pp. 71-76.

[67] Spyrou, S. (2001)."Stock Returns and Inflation: Evidence from an Emerging Market”, Applied Economic Letters, 8(7): pp. 447-450.

[68] Toda, H.Y., Yamamoto, T. (1995), "Statistical inference in vector autoregressive with possibly integrated processes". Journal of Econometrics, 66(1), pp. 255-250.

[69] Umut H (2010).“Testing long run relationship between stock market and macroeconomic variables in the presence of structural breaks: the Turkish case", Int. J. Financ. Econ., 48:51-56.

[70] Urich, T. and P. Wachtel (1981), "Market response to the weekly money supply announcements in the 1970s", Journal of Finance, 36, pp. 1063-1072.

[71] Wongbampo, P. and Sharma, S.C. (2002), "Stock Market and Macroeconomic Fundamental Dynamic Interactions: ASEAN-5 Countries", Journal of Asian Economics, Vol. 13, pp. 27-51.

[72] Yeh, C.C and C.F. Chi (2009)."The Co-Movement and Long-Run Relationship between Inflation and Stock Returns: Evidence from 12 OECD Countries". Journal of Economics and Management. 5(2): pp. 167-186.

[73] Zhao, X.-Q. (1999). "Stock Prices, Inflation and Output: Evidence from China". Applied Economics Letters, 6: pp. 509-511. 